九州大学学術情報リポジトリ

Kyushu University Institutional Repository

\title{
Transport of Thymidine inte the Developing Silk Gland as a Rate-limiting Step for the Formation of DNA Precursors.
}

Takechi, Kazuo

Laboratory of Sericultural Chemistry, Faculty of Agriculture, Kyushu University

Koga, Katsumi

Laboratory of Sericultural Chemistry, Faculty of Agriculture, Kyushu University

Hayashi, Katsuya

Laboratory of Sericultural Chemistry, Faculty of Agriculture, Kyushu University

https://doi.org/10.5109/23669

出版情報: 九州大学大学院農学研究院紀要. 22 (4)，pp.227-232，1978-07. Kyushu University バージョン：

権利関係 : 


\title{
Transport of Thymidine inte the Developing Silk Gland as a Rate-limiting Step for the Formation of DNA Precursors.
}

\author{
Kazuo Takechi*, Katsumi Koga and Katsuya Hayashi \\ Laboratory of Sericultural Chemistry, Faculty of Agriculture, \\ Kyushu University 46-02, Fukuoka 812
}

(Received March 7, 1978)

\begin{abstract}
Developmental changes in the rate of thymidine uptake into the posterior silk gland of Bombyx mori was investigated by incubating the organ in a medium containing labelled thymidine. In the glands taken at day 2 of the 5 th instar when the gland rapidly synthesizes DNA, the whole cell uptake of thymidine followed Michaelis-Menten kinetics with an apparent $K_{m}^{\prime}$ of $25 \mu \mathrm{M}$. This value was larger than the measured concentration of thymidine (1 to $2 \mu \mathrm{M}$ ) in the hemolymph where the glands originally exist, and smaller than the $K_{m}$ of the silk gland thymidine kinase (for the thymidine substrate) as determined by a partially purified enzyme $(3.3 \mu \mathrm{M})$. On the other hand, the older silk glands in which the rate of DNA synthesis is low (day 4 of the 5th instar) incorporated thymidine with kinetics less of the Michaelis-Menten type but in more of a linear manner; the apparent $K_{m}^{\prime}$ value for the whole cell uptake of thymidine became as high as about 1 $\mathrm{mM}$. These findings suggest that the uptake system of the silk gland for extracellular thymidine may serve as a rate-limiting step in the formation of steady state intracellular thymidylate pools.
\end{abstract}

\section{INTRODUCTION}

The rate of incorporation of thymidine into DNA precursors is known to correlate well with the growth of cells in many biological systems (e.g. see Sneider et al., 1969; Plagemann and Erbe, 1972). The silk gland of Bo mbyx mori also exhibits a high level of thymidine-phosphrylating enzyme, thymididine kinase, in parallel with the rate of DNA synthesis (Turenne et Daillie, 1973; Moriuchi et al., 1972). The silk gland can be easily incubated in an artificial medium and has been a convenient tool for study of the mode of incorporation of external thymidine into nucleotide pools as well as DNA (Daillie, 1967a, b, c; Turenne et Daillie, 1969). The present study is an extension along this line. Our results suggest that the gland possesses an active transport system for thymidine, and this system functions only when DNA synthesis takes place.

* Present address: Central Research Laboratories of Green Cross Corporation, Miyakojima, Osaka 534 


\section{MATERIALS AND METHODS}

\section{Animals}

Silkworms of hybrid strains were used. They were reared on mulberry leaves at $25 \pm 11^{\circ} \mathrm{C}$ and $55 \pm 5 \%$ r.h. Animals of mean weight (both sexes) were collected at indicated period, and silk glands were taken in physiological saline, washed, and immediately used for experiments.

\section{Medium and incubation system}

The medium for incubation and the conditions for culture were essentially the same as previously published (Daillie, 1967a; Turenne et Daillie, 1969). The organ was used without preincubation, and the internal pools of thymidine and thymidylates may not be deprived. Two pairs of the gland was incubated in $5 \mathrm{ml}$ medium containing $1 \mu \mathrm{Ci}$ thymidine-6- ${ }^{3} \mathrm{H}(10 \mathrm{Ci} / \mathrm{mmole}$, Daiichi Pure Chemicals Co.) in a $50 \mathrm{ml}$ conical flask. The final concentration of thymidine was $0.02 \mu \mathrm{M}$. Sometimes, cold thymidine was added to obtain higher concentrations of thymidine. The temperature applied was $30^{\circ} \mathrm{C}$, and the flask was shaken at $75 \mathrm{~Hz}$ per min.

\section{Analysis of cell fractions}

The standard Schmidt-Thannhauser-Schneider method was modified as follows: The glands were homogenized in $3 \mathrm{ml} 5 \%$ perchloric acid and the precipitate formed was washed with $2 \mathrm{ml} 5 \%$ perchloric acid. The combined supernatant was used as the acid soluble fraction. The precipitate was directly treated with $0.3 \mathrm{~N} \mathrm{KOH}$ at $37^{\circ} \mathrm{C}$ overnight, acidified with perchloric acid, and the resulting precipitate was collected (the supernatant contained RNA fraction in which incorporation of thymidine was neglected; alcohol soluble fraction was also omitted from analysis although this might contain some metabolites as seen by Daillie, 1967c). The precipitate was dissolved by heating in $3 \mathrm{ml} 5 \%$ perchloric acid at $100^{\circ} \mathrm{C}$ for $15 \mathrm{~min}$ and the supernatant was collected as the DNA fraction. All the procedures were conducted at 0 to $4^{\circ} \mathrm{C}$ except otherwise indicated. Aliquots $(0.5 \mathrm{ml})$ of the fractions thus obtained were each mixed with $4 \mathrm{ml}$ ethanol and $5 \mathrm{ml}$ toluene-PPO, and counted with a scintillation spectrometer. Sometimes, the acid-soluble fraction was subdivided into intact thymidine and thymidine phosphates by Avicel SF thin layer cellulose plates with isopropanol- $\mathrm{H}_{2} \mathrm{O}-28 \%$ ammonium water $(85: 15: 1.3)$ as a solvent. The fractions were scraped, extracted in water and counted as above.

\section{Other analyses}

Conventional isotope dilution was applied (e.g. Gross and Rabinowitz, 1968) for the analysis of the thymidine concentration in the hemolymph (or blood). The activity of thymidine kinase was assayed as described previously (Moriuchi et al., 1972). 


\section{RESULTS}

Time course of uptake of thymidine into DNA fraction and acid soluble fraction

Silk glands taken at day $\mathbf{2}$ of the 5th instar was incubated in the medium containing either a low or high concentration of ${ }^{3} \mathrm{H}$-thymidine (Fig. 1). At a low concentration $(0.02 \mu \mathrm{M})$, the rate of incorporation into DNA was linear from time zero, suggesting that thymidine bypassed preexisting thymidylate pools. This may be interpreted in terms of compartmentalization of thymidine nucleotide pools (Turenne et Daillie, 1969; Kuebbing and Werner, 1975). At a high concentration of thymidine $(2 \mu \mathrm{M})$, in contrast, the label was significantly diluted at the initial several minutes of incubation, suggesting that thymidine passed through the internal pools. The rates of uptake of label into DNA under both conditions were similar; the amount of thymidine incorporated may be proportional to the extracellular thymidine concentration at least at the range of concentration applied. It is interest to note that the higher concentration utilized here is close to the physiological value of blood thymidine level (see below).

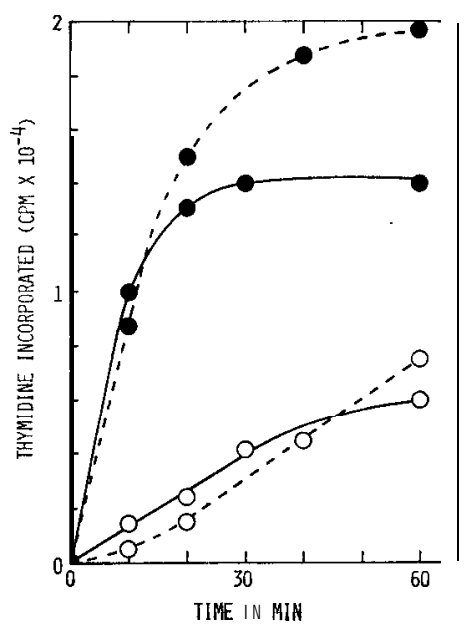

Fig. 1. Time course of uptake of extracellular thymidine into cell fractions. The posterior silk glands were taken at day 2 of the 5 th instar, and incubated in vitro with radioactive thymidine. The final concetration of the latter was $0.02 \mu \mathrm{M}(\longrightarrow$ or $2 \mu \mathrm{M}(\cdots \cdots) \cdot$, total fractions (acid soluble fraction plus DNA fraction); 0, DNA fraction.

\section{Developmental changes in rate of uptake}

By using the sub-physiological concentration of thymidine $(0.02 \mu \mathrm{M})$ which does not disturb the internal pools, daily changes of the rate of uptake into cell fractions were studied. The incorporation period of $30 \mathrm{~min}$ was chosen because of technical reasons, although this incorporation did not represent the strict initial velocity of whole cell uptake (see Fig. 1). As shown in Fig. 2, the incorporation of thymidine into total cell fractions was maximum at 


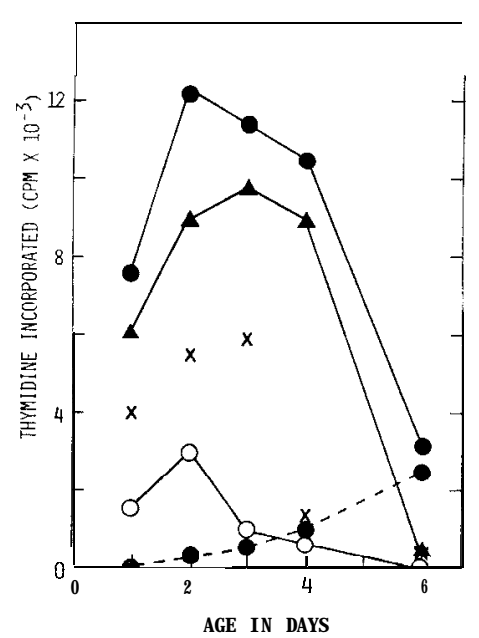

Fig. 2. Developmental changes in rate of thymidine uptake into cell fractions. The posterior silk glands taken at indicated days of the 5 th instar were incubated with $0.02 \mu \mathrm{M}$ radioactive thymidine for $30 \mathrm{~min}$.

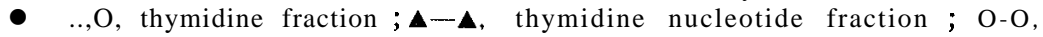
DNA fraction. Totalized counts were also illustrated - The activity of thymidine kinase in the posterior silk gland was assayed and expressed in arbitrary units $(\mathbf{x})$. The maximum of DNA synthesis rate was found at day 2 but the day changed according to the series of animals used.

day 2, when the DNA-synthesizing rate was maximum. The activity of thymidine kinase was also at a high level on this day. The incorporated thymidine was rapidly phosphorylated and scarcely remained intact (see the thymidine plot in Fig. 2). At day 4, thymidine was only very slowly incorporated into DNA, but the total uptake of thymidine was still significant and the incorporated thymidine was also rapidly metabolized into the thymidylate pool. Finally, at day 6 of the instar, the total uptake became extremely low, and the incorporated thymidine was no more metabolized.

\section{Developmental changes in kinetics}

The mode of incorporation was studied as a function of external thymidine concentration, by using the silk glands taken at different ages. Figure 3 shows the results. The younger silk glands (day 2) incorporated thymidine with typical Michaelis-Menten kinetics, showing a $K_{m}^{\prime}$ value at $25 \mu \mathrm{M}$ (the pattern of the double reciprocal plot was omitted). This may indicate that the uptake is not a passive process but is accelerated by some transport system. Moreover, we found that the above value of $K_{m}^{\prime}$ was much larger than the concentration of thymidine in the blood which was measured to be $1.67 \mu \mathrm{M}$ at day 2 . These findings suggest that, if the supply of blood thymidine may change developmentally, it would affect the level of intracellular thymidine nucleotides. This may not be the case, however; because the thymidine concentration in the blood did not change extensively, and still kept a 


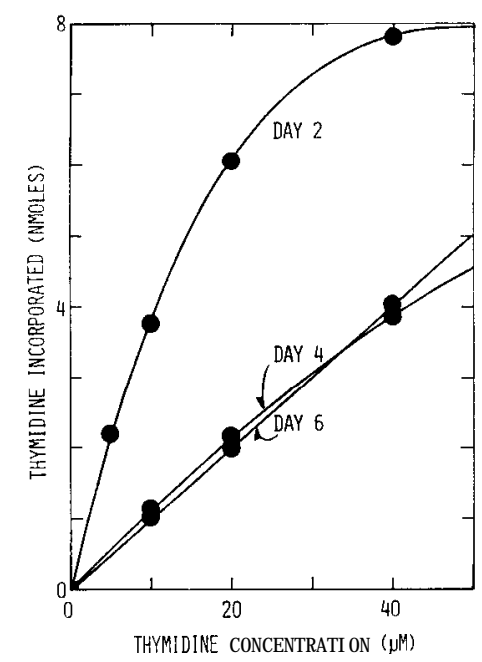

Fig. 3. Thymidine uptake as a function of thymidine concentration. The posterior silk glands were taken at days 2, 4, or 6, and incubated as described in Fig. 2 but thymidine concentration was varied as indicated. The sum of acid soluble fraction and DNA fraction was illustrated.

level at $1.26 \mu \mathrm{M}$ at day 4 . Instead, the activity of the gland dramatically changed as seen by the curves shown in Fig. 3. At day 4 , the $K_{m}^{\prime}$ for thymidine was as high as $1 \mathrm{mM}$ (this value depended upon conditions). By day 6 , the blood level of thymidine had only slightly lowered (1.07 $\mathrm{PM})$, but the rate of incorporation of thymidine had become much smaller (Fig. 2). The latter uptake no more followed Michaelis-Menten kinetics but was linear against the external thymidine concentration (Fig. 3), indicating that simple diffusion predominated at this period.

On the whole, a transport system may be the main rate-limiting step for the formation of intracellular thymidylate pools.

\section{DISCUSSION}

The silk gland of Bombyx mori may incorporate blood thymidine by an active transport process when the cells synthesize DNA. This is indicated by the fact that the uptake followed Michaelis-Menten kinetics (see above), and that the rate of incorporation depended on temperature (Takechi, unpublished results). When the rate of DNA synthesis became low, the transport system was replaced by simple diffusion. The incorporated thymidine was rapidly phosphorylated by thymidine kinase. All these findings support the idea that the uptake process may limit the level of nucleotide pools in the cell. This inference is further substantiated by comparison of the $K_{m}^{\prime}$ of the total cell uptake $(25 \mu \mathrm{M})$ with the $K_{m}$ of thymidine kinase $(3.3 \mu \mathrm{M})$ for thymidine. The latter value was determined by a partially purified enzyme preparation extracted from the posterior silk gland (Takechi, unpublished results). 
At day 4 of the 5th instar, the rate of DNA synthesis and the activity of thymidine kinase decreased, while thymidine nucleotide pool was still large (Fig. 2). This discrepancey may be explained by assuming that the steady state concentration of the nucleotide pool is relatively constant, but the flow rate decreases more greatly. This assumption is compatible with the above mentioned developemental change of $K_{m}^{\prime}$ of the gland against the extracellular thymidine.

The precise relationships between the thymidine uptake system and the compartmentalization of thymidylate pools remain to be elucidated. Whether the well-discussed "feedback" of thymidine kinase by thymidine triphosphate (Okazaki and Kornberg, 1964) indeed functions in the cell is also of interest. Thus the thymidine system will offer an excellent tool for study of metabolic regulation.

\section{REFERENCES}

Daillie, J. 1967a Metabolisme de la thymidine dans la glande séricigène du ver a soie, I. Les principales voies suivies par le précurseur dans la glande incubee in vitro. Ann. Biol. Anim. Bioch. Biophys.. I: 115-129

Daillie, T. 1967b Metabolisme de la thymidine dans la glande séricigène du ver a soie. II. Utilization des nucleotides radioactifs pour la synthèse de 1'ADN dans la glande incubee in vitro au $4^{\mathrm{e}}$ jour du $5^{\mathrm{e}}$ stade. Ann. Biol. Anim. Bioch. Biophys., 7 : 227-243

Daillie, J. 1967c Métabolisme de la thymidine dans la glande séricigène du ver a soie. III. Incorporation de la thymidine radioactive dans la glande séricigène prélevèe au $6^{\mathrm{e}}$ jour du 5" age et incubee in vitro. Ann. Biol. Anim. Bioch. Biophs., 1: 347-354

Gross, N. and M. Rabinowitz 1968 Thymidine content and turnover in the rat. Biochim. Biophys. Acta, 157: 648-651

Kuebbing, D. and R. Werner 1975 A model for compartmentation of de novo and salvage thymidine nucleotide pools in mammalian cells. Proc. Nat. Acad. Sri. U SA, 72: 33333336

Moriuchi, A., K. Koga, J. Yamada and S. Akune 1972 DNA synthesis and activities of pyrimidine-synthesizing enzymes in the silk gland of Bombyx mori. J. Insect Physiol., $18: 1463-1476$

Okazaki, R. and A. Kornberg 1964 Deoxythymidine kinase of Escherichia coli. II. Kinetics and feedback control. J. Biol. Chem., 239: 275-284

Plagemann, P. G. W. and J. Erbe 1972 Thymidine transport by cultured Novikoff hepatoma cells and uptake by simple diffusion and relationship to incorporation into deoxyribonucleic acid. J.Cell Biol., $55: 161-178$

Sneider. T. W.. V. R. Potter and P. Morris 1969 Enzymes of thymidine triphosphate synthesis in selected Morris hepatomas. Can. Res., 29: 40-54

Turenne, M. de et J. Daillie 1969 Utilization de la thymidine exogene parlaglandeséricigène du ver a soie incubee in vitro. II. Compartimentage des nucleotides intracellulaires d'origine exogene. Biochim. Biophys. Acta, 186: 267-279

Turenne, M. de et J. Daillie 1973 Regulation de la synthèse du DNA dans la glande séricigene de Bombyx mori. I. Etude des thymidine- et thymidylate-kinases de la fraction soluble brute. Biochimie, 55 : 1439-1447 